International Journal of Advanced Geosciences, 2 (2) (2014) 59-65
International Journal of Advanced Geosciences
Journal home page: $\begin{gathered}\text { www.sciencepubco.com/index.php/IJAG } \\ \text { doi: } 10.14419 / \text { ijag.v2i2.2452 } \\ \text { Research Paper }\end{gathered}$

\title{
Identification and mapping of the water-logged areas in Purba Medinipur part of Keleghai river basin, India: RS and GIS methods
}

\author{
Abhay Sankar Sahu \\ Department of Geography, University of Kalyani, Nadia 741235, West Bengal, India \\ E-mail: sahu.abhaysankar@gmail.com
}

\begin{abstract}
The prime objective of this paper is to identify and mapping of the water-logged areas applying methods of Remote Sensing (RS) and Geographical Information System (GIS) in the part of Purba Medinipur district of Keleghai river basin, India. For this purpose, USGS Landsat 8 imagery (4th November, 2013) and topographical sheets (scale - 1:50,000; year - 1970) have been used here, processing through Arc GIS 9.3 and ERDAS Imagine 9.1, with field observations. A supervised classification of Landsat 8 imagery (2013) of the study area has been made after conversion of DN value to Top of Atmosphere (TOA) radiance value, and it is found that the amount of water-logged areas is $80-\mathrm{km}^{2}$. Based on different maps, it is observed that the factors like relief, slope, embankment density and settlement density have disproportionate relationship and canal density has direct proportion with the spatial distribution of water-logged areas. Here, RS techniques like NDVI, NDWI and modified NDWI or NDMI have been followed to corroborate water-logged areas and finally to understand the relevance of these techniques toward mapping of the water-logged areas, a Correlation Matrix has been prepared using SPSS 20 software and in result they are acceptable for an understanding on water-logged areas as values of them are significantly correlated with canal density.
\end{abstract}

Keywords: Water-Logged Areas, Low-Lying Areas, Canal Density, RS Techniques, Correlation Matrix.

\section{Introduction}

Today the Remote Sensing (RS) and Geographical Information System (GIS) have widely been applied for the purpose of analysis of earth surface with changing space and time. It is necessary, a spatial as well as an environmental analysis of an area towards the regional as well as national planning and management. Throughout the world, water-logged environment found to be formed due to various physical and manmade factors. Water-logging is treated as natural and/or quasi-natural hazard in the rural areas. Waterlogging, is an environmental problem and it is found throughout the world (Bowonder et al. 1986) over China (Quan et al. 2010), Pakistan (Qureshi et al. 2008), Bangladesh (Tutu 2005, Minar et al. 2013), India (Choubey 1998, Chowdary 2008), and others. Generally, it is found to be created in the places of low-lying areas with the absence of high slope variations. When an area remains low-elevated than its surrounding areas and the surface soil does not pass the rainwater to the deep earth layers or the groundwater level is very near to the earth surface then at that place waterlogging can be initiated. The seasonal water-logging environment considered as a hazard to the local inhabitants as it disturbs the surface transport system. To delineate the small pockets of waterlogged areas, remote sensing data may be effective (Dwivedi 1994). In India, Choubey (1998) made a study on identification of water-logged areas in Sriram Sagar command area by remote sensing. Bhaker (2011) mentioned that surface expression of water-logged areas can be captured on the satellite imagery. Various methods like Water Index, Salinity Index, Normalised Differential
Salinity Index, Brightness Index, Vegetation Indices and Wetness Index are used in order to map the areas under risk of waterlogging considering different band ratios of LISS data (Bhaker 2011). The Landsat 8 imagery with the help of Arc GIS 9.3 software depicts a band combination of five, six and four to visualise land / water differentiation sharply (ESRI 2014). There are several methods and techniques of the remote sensing and GIS to identify differently land and water considering band variations of different multi-spectral images. Here the prime objective is the identification and mapping of the water-logged areas based on the USGS Landsat 8 (2013) imagery applying the methods of remote sensing and GIS in the part of Purba Medinipur district of Keleghai river basin. Then, it is to review the relationship between different factors, which are responsible for the creation of water-logged environment. Normalised Difference Vegetation Index (NDVI), Normalised Difference Water Index (NDWI) and Normalised Difference Moisture Index (NDMI) have been employed here to identify and mapping of the water-logged areas. Finally, it is to evaluate through a statistical technique the relevance of these RS methods to identify as well as to understand water-logged areas.

\section{Study areas}

The part of Purba Medinipur district of Keleghai river basin in the state of West Bengal, India, is extended from $22^{\circ} 01^{\prime} 15^{\prime \prime} \mathrm{N}$ to $22^{\circ}$ $12^{\prime} 10^{\prime \prime} \mathrm{N}$ latitude and $87^{\circ} 28^{\prime} 28^{\prime \prime} \mathrm{E}$ to $87^{\circ} 50^{\prime} 00^{\prime \prime} \mathrm{E}$ longitude (Fig. $1)$. It has an area of about $145-\mathrm{km}^{2}$. It is known to all as a flood prone area with consisting low-lying areas (DMP 2002, 2004, 
2007, and 2011). Elevation ranges from nearly one metre to 11metre throughout the study area, but maximum areas under study

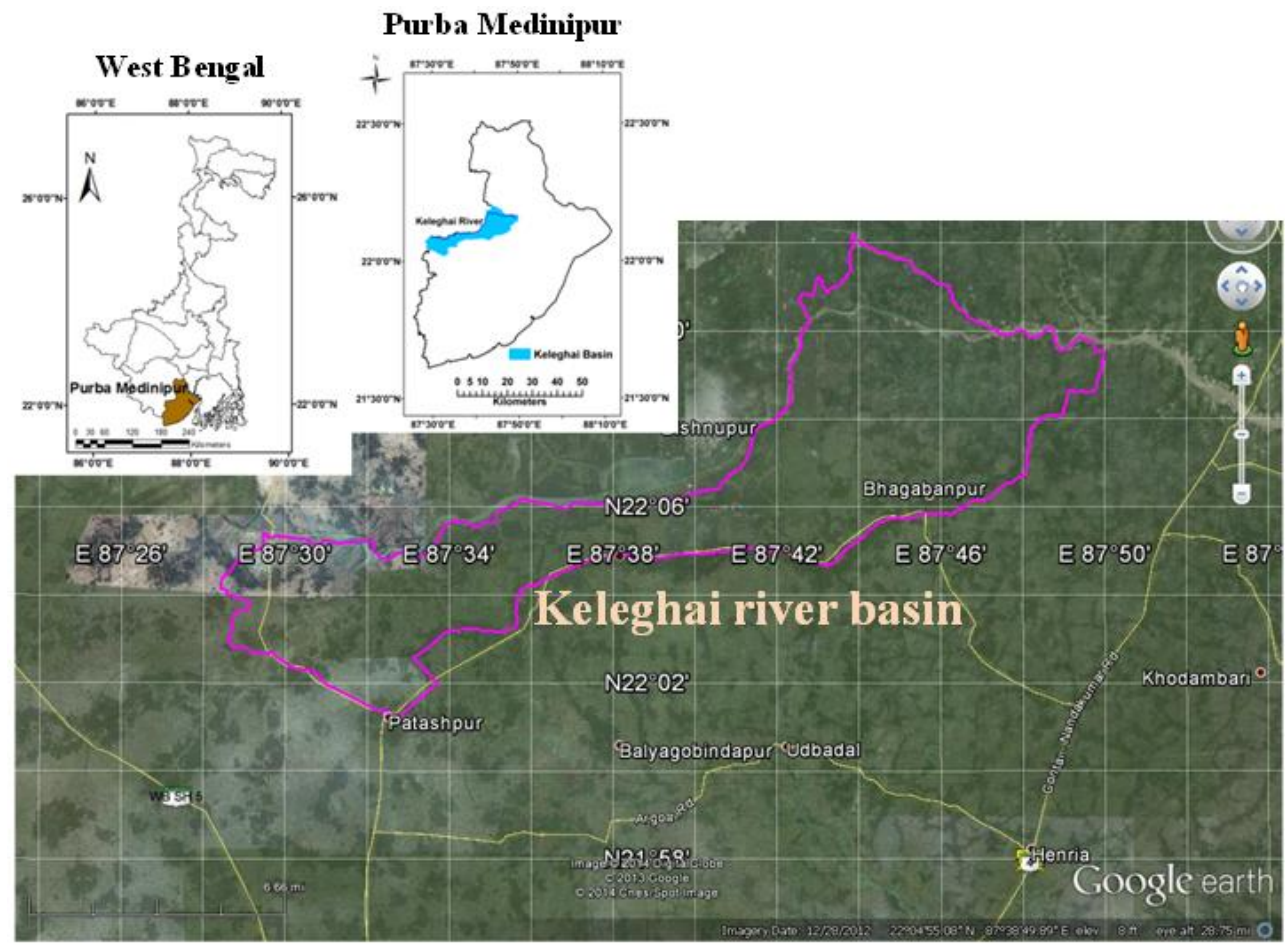

Fig. 1: Study Area

\section{Methods and materials}

Fig. 2 shows a flow chart to understand the methods and materials used here to fulfil our objective. Here, from the topographical sheets (scale - 1:50,000; year - 1970) 73 N/8, 73 N/12, and 73 N/16, after processing through Arc GIS 9.3 software, a relief map to represent elevation variations and contour lines within the study area; a slope map to depict the slope variations; one embankment density map; then a settlement density map; and a canal density map have been prepared. Thereafter, with the help of same software, dividing the study area into equal sized square grids $\left(30^{\prime \prime} \mathrm{X}\right.$ 30 "), taking 318 points (one middle most point / grid); data on: elevation, slope, embankment density, settlement density, and canal density extracted corresponding to every point consecutively. On the other hand, from the USGS Landsat 8 imagery (dated: $4^{\text {th }}$ November, 2013), with the help of Arc GIS 9.3 and ERDAS Imagine 9.1 software, after band wise conversion of the quantised and calibrated scaled Digital Number (DN), known as DN value of the bands, to Top of Atmosphere (TOA) radiance value, a supervised classification of the study area has been made to crop out and to understand the water-logged areas. Then, with the help of previously mentioned two-software, using certain formula for the Landsat 8 bands, maps on NDVI, NDWI, and modified NDWI or NDMI have been prepared. Here, values on NDVI, NDWI and NDMI corresponding to the previous 318 points all together have also been extracted. Now, based on SPSS 20 software, Spearman's Correlation Matrix has been prepared, taking the values of relief, slope, embankment density, settlement density, canal density, NDVI, NDWI, and NDMI, to examine and also to understand these three methods, NDVI, NDWI, and NDMI, are acceptable or not to examine water-logged areas. Above all, the study area has been surveyed several times at the time of rainy season and also post rainy season for field checking. It is an empirical study to identify and also to understand the water-logged environment as well.

\subsection{Conversion of DN to TOA radiance}

The DN values, of the Landsat 8 (2013) of USGS EROS Centre, converted to TOA spectral radiance using the radiance rescaling factors provided in the metadata file. The conversion formula is $L_{\lambda}$ $=M_{L} Q_{c a l}+A_{L}$. Where: $\mathrm{L}_{\lambda}=$ TOA spectral radiance; $\mathrm{M}_{\mathrm{L}}=$ Bandspecific multiplicative rescaling factor from the metadata; $A_{L}=$ Band-specific additive rescaling factor from the metadata; $\mathrm{Q}_{\mathrm{cal}}=$ Quantised and calibrated standard product pixel values (DN).

\subsection{NDVI, NDWI, and modified NDWI or NDMI}

Tucker (1979) developed the Normalised Difference Vegetation Index (NDVI) using the two bands of light: red and near-infrared. It is used to measure of the vegetation cover and also water bodies over the earth surface (Tucker and Choudhury 1987, Jackson and Huete 1991). NDVI is determined by the chlorophyll absorption in the red wavelengths, which is proportional to leaf chlorophyll density, and by the reflectance of near infrared radiation, a function of green leaf density (Tucker et al. 1985). NDVI is influenced by also a number of factors other than the green vegetation (Nicholson and Farrar 1994). Following Tucker (1979), it is found that the NDVI value ranges from -1 to +1 . Here, +1 describes the dense vegetation. Water typically has an NDVI value of less than zero. Here, -1 signifies the presence of extensive deep water bodies. Holben (1986) presented some typical NDVI values for various types of land use / land cover where water refers to the value of -0.257 . For a study, Dwivedi and Sreeniwas (2002) considered NDVI value of 0.13 as a threshold value for segregating vegetated areas from water-logged areas using Landsat MSS and TM, and IRS-1A LISS-I data. When it is the Landsat 8 imagery, then NDVI can be calculated using the formula: $N D V I=($ Band $5-$ Band 4$)$ (Band $5+$ Band 4 ), following the formula for Thematic Mapper (TM) and Enhanced Thematic Mapper Plus (ETM+) bands. Here, for Landsat 8, band five instead of band four for Near-infrared (NIR) and band four instead of band three for Red have been used to match the wave length variations between Landsat 8 and other Landsat series. Normalised Difference Water Index (NDWI) of McFeeters (1996) and Xu (2006) is to achieve the signature differ- 
ences between water and other targets through analysing signature features of each ground target among different spectral bands, and then to delineate land from open water. NDWI shows the opposite result of NDVI. As per Sims and Gamon (2003), the NDWI is an appropriate water absorption index in comparison with NDVI. It also ranges from -1 to +1 (McFeeters 1996). Chowdary (2008) mentioned that it is for water-logged areas ranges from zero to +1 . Here, +1 signifies the presence of extensive deep water bodies and -1 is for vegetation cover. From the Landsat 8 imagery, following McFeeters (1996), NDWI can also be calculated using the formula as follows: $N D W I=($ Band $3-$ Band 5$) /($ Band $3+$ Band 5 $)$, following the formula for TM and ETM+ bands. Here, for Landsat 8 , band three instead of band two for Green and band five instead of band four for Near-infrared (NIR) have been used to match the wave length variations of Landsat series. GAO (1996) and Huang et al. (2009) presented a modified Normalised Difference Water Index (NDWI) to minimise the errors of NDWI on soil water monitoring using Near-infrared (NIR) as earlier and Middleinfrared (MIR) instead of green band of the TM data. It is also known as $\mathrm{NDWI}_{\mathrm{GAO}}$. In the TM data, NIR presented by band four and MIR presented by band five to identify soil moisture in a better way. Wilson and Sader (2002) also used same band composites like $\mathrm{NDWI}_{\mathrm{GAO}}$ to calculate the Normalised Difference Moisture Index (NDMI), aiming to soil moisture investigation. According to Crist and Cicone (1984) and Wilson and Sader (2002), NDWI and NDMI are theoretically similar to each other for detection of spatial variation of surface wetness. Here for the Landsat $8 \mathrm{im}-$ agery, to calculate $\mathrm{NDWI}_{\mathrm{GAO}}$ or NDMI, the formula is as follows: $N D W I_{G A O}$ or $N D M I=($ Band $5-$ Band 6$) /($ Band $5+$ Band 6$)$, following the formula for TM and ETM+ bands. When it is Landsat 8 then band five instead of band four for Near-infrared (NIR) and band six instead of band five for MIR have been used to match the wave length variations between Landsat 8 and Landsat $5 / 7$ satellite series. In NDMI, the high values indicate the existence of more soil moisture under massive water bodies and low values denote low soil moisture content.

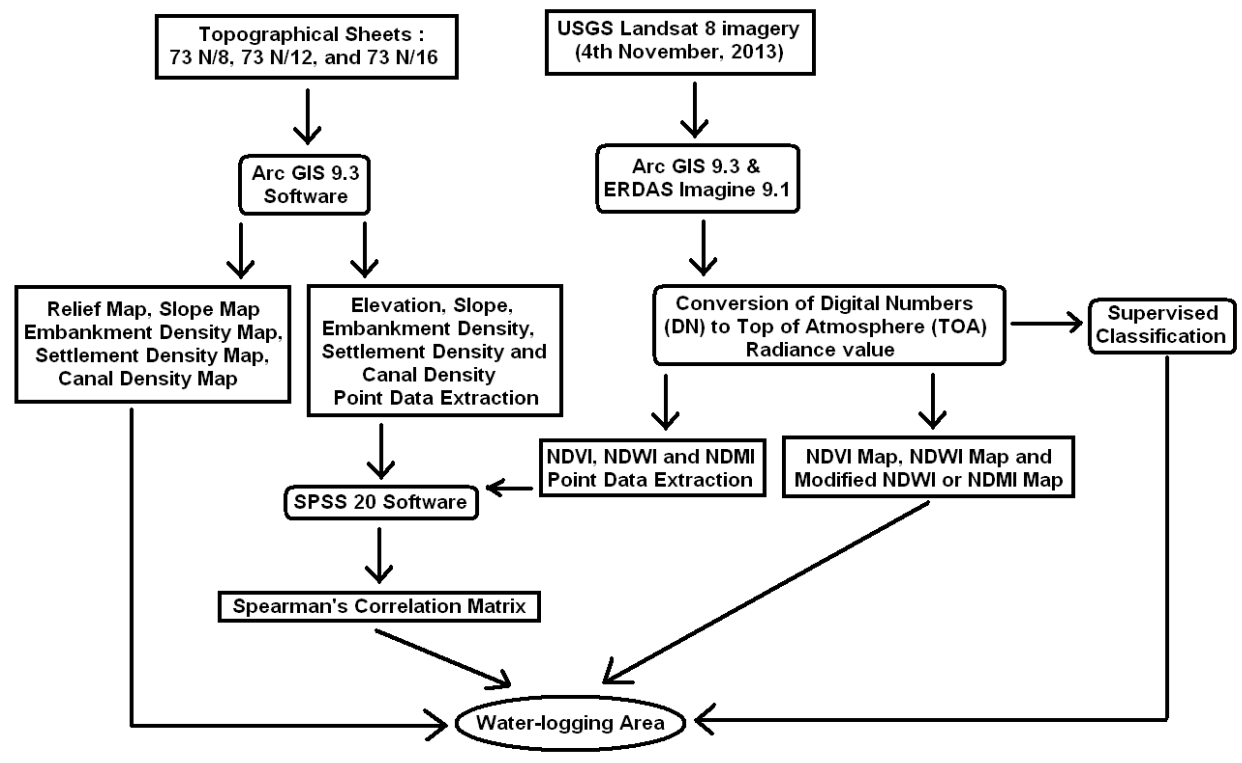

Fig. 2: Methods and Materials

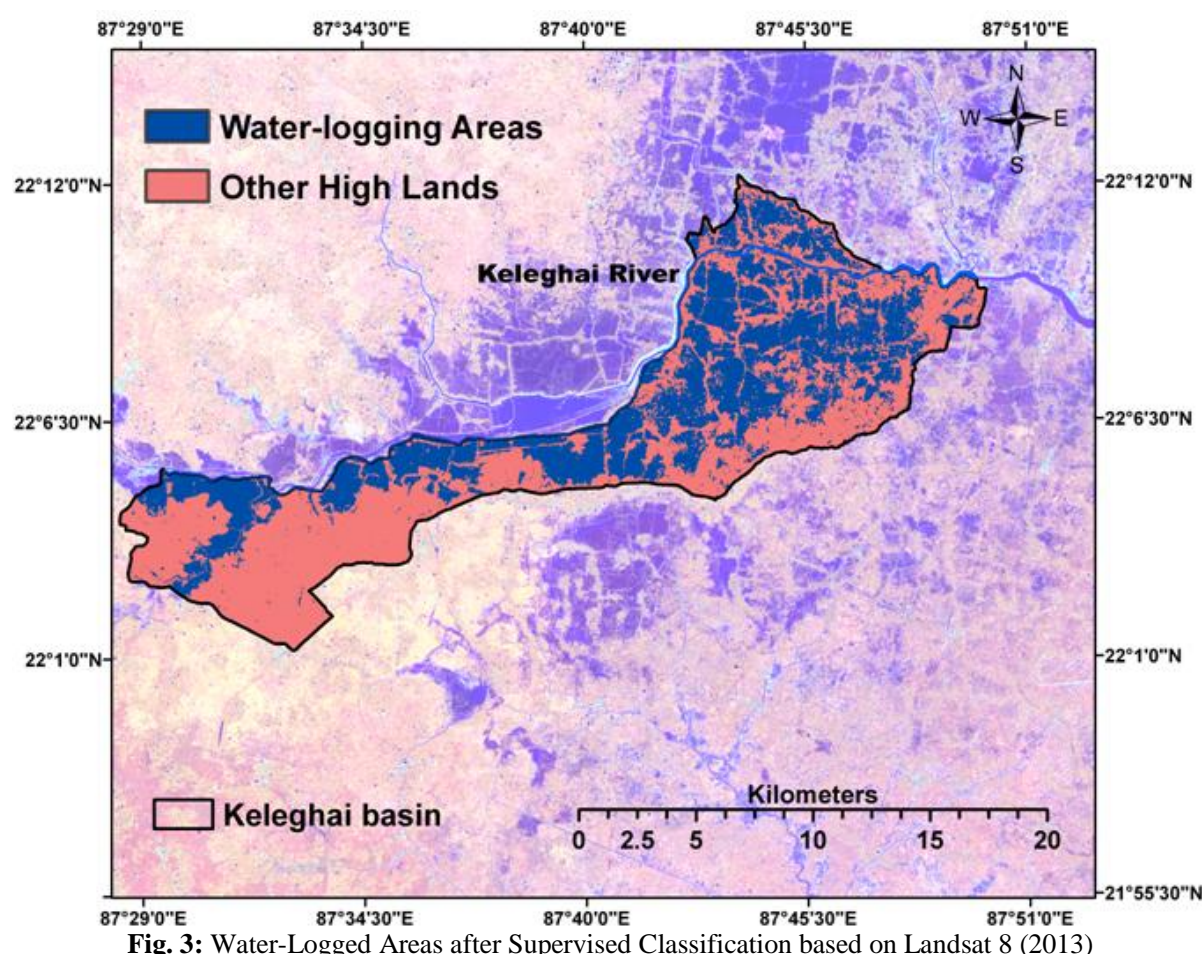




\section{Results}

The supervised classification of the Landsat 8 imagery (2013) reveals that the amount of water-logged areas is about $80-\mathrm{km}^{2}$ within the study area and these water-logged areas are found to be distributed along the river Keleghai and canals therein (Fig. 3, Fig. $4 \mathrm{e}$ and Fig. 4f). The elevation of this study area ranges from nearly one metre to 11-metre (Fig. 4a). Maximum areas have the relief characteristic within five to six metres. Here, in the study area, spot elevations are not very high from the sea level as well. There are only two remarkable highlands (nine to ten metres) found on the western part and northern corner of the study area. Fig. 4b shows the slope variation of the study area in degrees. Maximum areas have slope within 0.5-degree and also 0.5 to one degree. Only very negligible pockets have more than one degree slope.
Fig. $4 \mathrm{c}$ presents embankment density of the study area. The embankment density is high as much as nearly five- $\mathrm{km} / \mathrm{km}^{2}$. Fig. $4 \mathrm{~d}$ shows settlement density. Fig. $4 \mathrm{e}$ is for canal density of the study area as well. Here canals are the quasi-natural water-channels, locally known as 'khals'. Based on different solar reflectance value of the vegetative cover, soil moisture, water bodies, and so on, there are band wise variations in digital signature within the Landsat 8 imagery. From there, applying certain formula, mentioned in the methodology part, NDVI, NDWI, and modified NDWI or NDMI have been prepared (Fig. 5). Fig. 5a shows the map on NDVI and there the value of NDVI ranges from -0.47 to +0.56 . Fig. $5 \mathrm{~b}$ shows the map on NDWI. Here the value ranges from -0.34 to +0.59 . Fig. $5 c$ is the map on modified NDWI or NDMI where the value ranges from 0.50 to 0.95 .

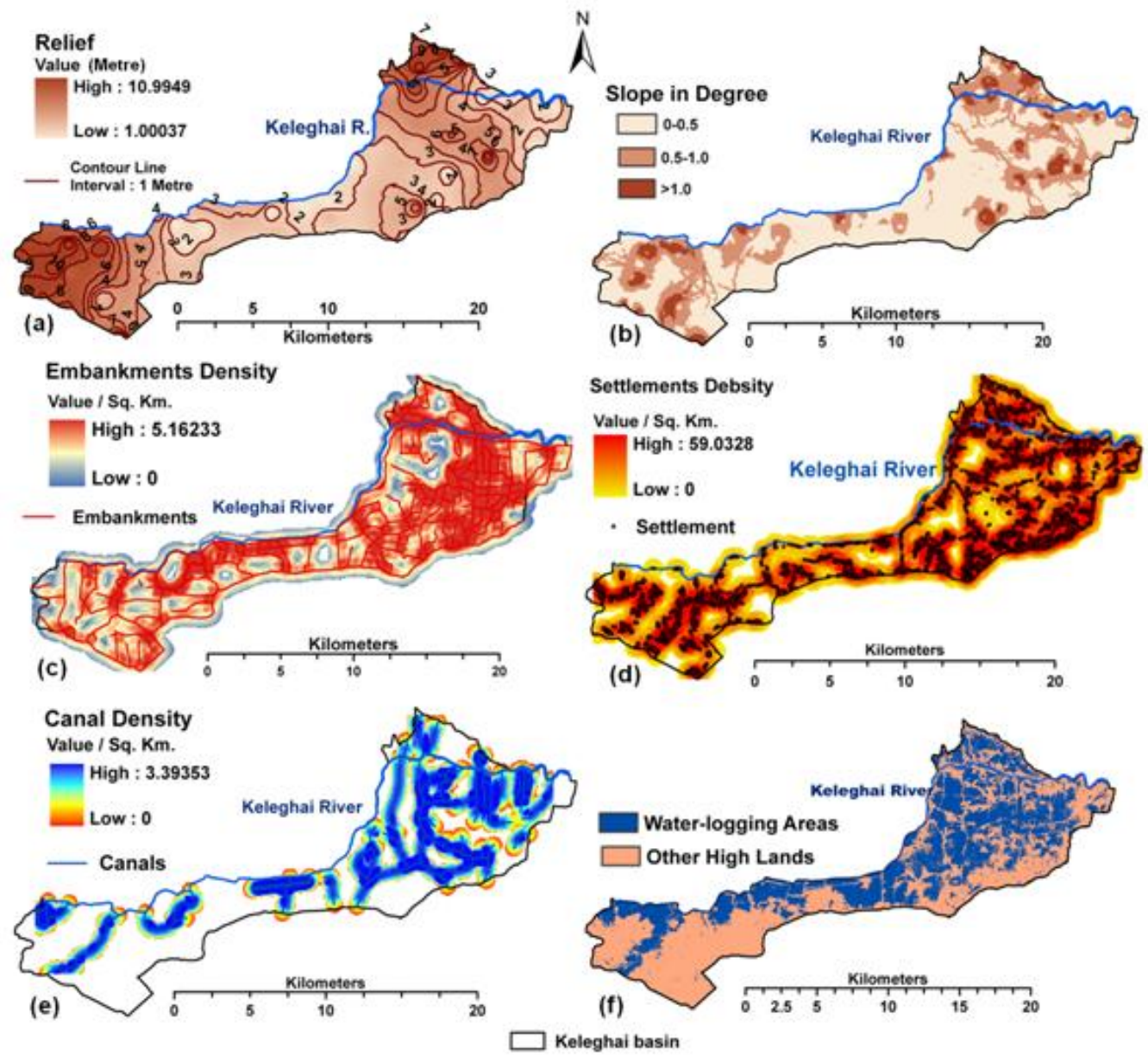

Fig. 4: Relationship Between (A) Relief, (B) Slope, (C) Embankments Density, (D) Settlements Density, (E) Canal Density, and (F) Water-Logged Areas based on Topographical Sheets: 73 N/8, 73 N/12, and 73 N/16 (1970); Landsat 8 (2013)

\section{Discussions}

In India, up to the late fifties and middle of sixties of the $20^{\text {th }}$ century, extensive areas within the various states were water-logged due to poor upkeep and maintenance of main surface drains (Gupta 2002). According to Mukherjee (1985), the lower reaches of the state of West Bengal remained water-logged for a long time due to accumulated floodwater; where this study area is also situated. In the time of field survey, local inhabitants said that from the historic past, water-logging is commonly found in this study area. In the early periods of twentieth century, due to prevailing water-logged condition, there canals were the main transport and communication medium to the local inhabitants. In the Keleghai river basin area, it is found that every year water-logged situation initiated during the period of late July to early August. It is con- tinued up to December and early January. It is very much fluctuated with the onset of rainy season (Malik et al. 2002). Throughout the Purba Medinipur district, annual average rainfall is 1746.6$\mathrm{mm}$. (agricoop.nic.in, 2011). When monsoon rain comes first then water-logged condition is found to be employed in the beginning of rainy season and when it is late then the set-up of water-logged condition also be late. In the study area, most of the water-logged fields are agricultural lands. These are primarily low-lands than their surroundings. Water-logged environment in the study area is seasonal in nature and during the summer season these waterlogged fields transferred into dry lands. In the rainy season, due to water-logged condition, the soils of the study area become very wet and moist. Water-logged condition disturbs the local landtransport routs as the low-elevated embankments flooded under water with the low-lying areas. In the time of field survey, it is 
observed that local people engaged to cultivate different types of fishes with the help of accumulated rainwater in the low-lying areas particularly in the rainy season and thereafter. The waterlogged environment thus helps to the fishing activity and therefore the local economic system depends on it in addition to the paddy cultivation.

\subsection{Water-logging and others relationship based on to- pographical data}

There are several natural, quasi-natural and manmade factors responsible to the initiation of water-logged condition. Positional water-logging depends on two topographic factors and these factors control the probability of water-logging where water-logging increases with the contributing drainage area and decreases with increasing local slope angle (Merot et al. 1995). Again, Holden et al. (2009) mentioned that the water-logging is controlled by local geology, topography, drainage and the amount of water supplied to the site. Through a detailed field survey and also from Fig. 4a, it is found that most of the areas under study are low-lands. Fig. 4a depicts the relief variations with contour distribution towards a clear understanding on the distribution of water-logged areas in relation to them. Normally, the water-logged areas are low-lying fields surrounded by comparatively highlands. There slope is less where elevation variation is also low, and those places have possibility to create the water-logged situation. High sloped surface cannot allow water-logging. Generally, surface water flows following the slope direction and it is accumulated in the lowlands and low-sloped fields. In a comparison between Fig. 4a, Fig. 4b and Fig. 4f, it is found that low-elevated and less sloped surfaces have water-logged scenario. This truth is also observed in the time of field survey. These two factors, relief variation and slope characteristic are natural and water-logged condition is structurally controlled by these geomorphic setups in the study area. In the south-west coastal region of Bangladesh, during $17^{\text {th }}$ century, local land lords had constructed haphazard earthen embankments and thereafter during 1960s to protect agricultural lands Government of Bangladesh made a series of embankments, those in turn contributed water-logging therein (Tutu 2005, ERF 2011). Embankments are manmade features. Sometimes this factor creates waterlogging through surface water blocking and disrupting surface water runoff (Dwivedi 1994). Generally, in the flood prone areas, embankments are constructed on the highlands to avoid flooding effects. Due to this reason, embankment density is high in the high elevated lands; Fig. 4c also revealed that truth. In the study area, settlement density is high in the high elevated areas to avoid flooding and water-logged hazard. Fig. $4 d$ shows settlement density and it in comparison with Fig. 4f presents that water-logged areas are mismatched with the areas of high settlement density. Sometimes, settlement areas also blocked natural surface water flow and through this way water-logging may be created. In the study area, many houses are observed on the slopes of the embankments since embankments are highlands than the surrounding areas. Fig. 4e shows canal density of the study area. Canals are found to be distributed throughout the low-lying areas. In comparison between Fig. 4e and Fig. 4f, it is clearly observed that the canal density is high in the low-lying areas and at the same time these areas are water-logged also. Rainwater, after accumulation in the low-lying areas, flows through these canals. Thus and therefore, canals become an indicator of the water-logged condition consisting with low-lying areas.

\subsection{NDVI, NDWI and NDMI}

The value of NDVI (Fig. 5a), ranges from -0.47 to +0.56 , reveals that there is no any dense forest cover. Here the value +0.56 referred to the agricultural lands. Lowest values, near to -0.47 , indicate to the presence of water bodies. These are the water-logged areas. The spreading of lowest values of NDVI is similar with the water-logged areas of Fig. 3. As the value of NDWI for water is either equal to or greater than 0.32 (Chatterjee et al. 2005) then the NDWI value (Fig. 5b), ranges from -0.34 to +0.59 , represents some of the water-logged areas. It is just opposite to the NDVI. In this figure high values indicate the presence of water bodies. The modified NDWI or NDMI (Fig. 5c) clearly shows the areas of water bodies with similar to the NDVI and NDWI. High value (more than +0.20 ) of NDMI indicates moist soil surface with very good potentiality of ground water and from +.20 to +0.10 indicates wet to dry soil with moderate potentiality (Wilson and Sader 2002, Goodwin et al. 2008). Here the values range from 0.50 to 0.95 . In this index, high values represent the deep and extended water masses. These three figures $(5 \mathrm{a}, 5 \mathrm{~b}$ and $5 \mathrm{c})$ resemble with Fig. 3 to represent water-logged areas.
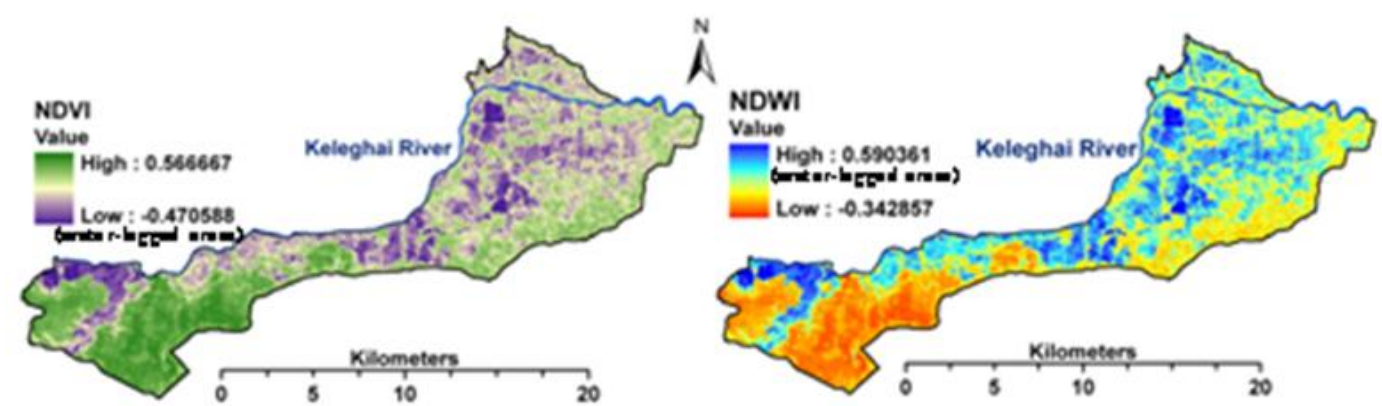

(a)

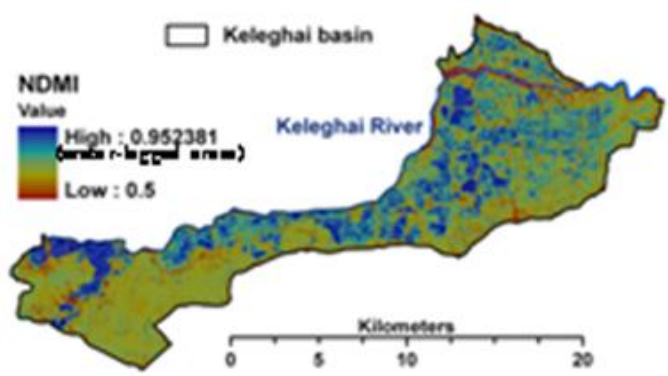

(b)

(c)

Fig. 5: (A) NDVI; (B) NDWI and (C) NDMI based on Landsat 8 (2013) 


\subsection{Statistical inquiry to search the relevance of NDVI, NDWI, and NDMI for understanding water-logged ar- eas}

With the help of SPSS 20 statistical software, a Spearman's Correlation Matrix (Table 1) has been prepared. There correlation as well as strength of association has been measured for relief, slope, embankment density, settlement density, canal density, NDVI, NDWI, and NDMI. In result, it is found that canal density is corre- lated by $99 \%$ significance level with relief, slope, settlement density, NDVI, NDWI, and NDMI, and also by $95 \%$ significance level with embankment density. It has already been previously discussed that the canal density is directly proportionate with the water-logged areas and here it is observed that the canal density is significantly correlated with the NDVI, NDWI and NDMI. Beside this, no other unit has significant relationship with the NDVI, NDWI, and NDMI.

Table 1: Spearman's Correlation Matrix

\begin{tabular}{ccccccccc}
\hline & relief & slope & embankment & settlement & canal & NDWI & NDVI & NDMI \\
\hline relief & 1 & $1.000^{* *}$ & -.013 & -.004 & $.173^{* * *}$ & .065 & -.069 & .016 \\
slope & & 1 & -.013 & -.003 & $.174^{* *}$ & .066 & -.069 & .016 \\
embankment & & & 1 & .095 & $.132^{*}$ & .048 & -.036 & .001 \\
settlement & & & & 1 & $.176^{* *}$ & .080 & -.077 & .001 \\
canal & & & & & 1 & $.300^{* *}$ & $-.284^{* * *}$ & $.220^{* *}$ \\
NDWI & & & & & & 1 & $-.996^{* *}$ & $.640^{* *}$ \\
NDVI & & & & & & & & $-.614^{* *}$ \\
NDMI & & & & & & & 1 \\
\hline
\end{tabular}

**Correlation is significant at the $99 \%$ level.

*Correlation is significant at the $95 \%$ level.

\section{Conclusion}

Applying the remote sensing method of supervised classification of the USGS Landsat 8 imagery of the dated of $4^{\text {th }}$ November, 2013, with the help of Arc GIS 9.3 software, it is found that the amount of water-logged areas is about $80-\mathrm{km}^{2}$ out of the total study area i.e. $145-\mathrm{km}^{2}$. The factors like relief and slope, which are natural, and manmade like embankment density and settlement density, all together have disproportionate relationship and quasinatural canal density has direct proportion with the spatial distribution of water-logged areas. Where the relief is high there the slope is also high along with the high embankment density and also the high settlement density, and there the amount of waterlogged areas is less. The amount of water-logged areas is high in the areas of high canal density. Now, it is found that the remote sensing methods, like NDVI, NDWI and modified NDWI or NDMI, are acceptable to identify and also for mapping purposes of the water-logged areas since these are significantly correlated with the canal density.

\section{Acknowledgement}

The author acknowledges University Grants Commission (UGC), New Delhi, India, for financial assistance. This paper has been prepared from the study under UGC-BSR Start-up Grant Scheme [Ref. UGC Letter No - F.20-3(17)/2012(BSR) Date: February, 2013 (08 March, 2013)] on 'Environmental Consequences of Water-Logging Problem in Purba Medinipur District, West Bengal: Evaluation, Mapping, and Management'.

\section{References}

[1] Agricoop.nic.in. 2011. Web. http://agricoop.nic.in/Agriculture $\% 20$ contingency $\% 20 \mathrm{Plan} /$ West $\% 20$ Bengal/WestBengal\%2015-Purba\%20Medinipur-31.12.2011.pdf . Accessed December 03, 2013.

[2] Bhakar R (2011) Recent Advances in Geo-informatics Based Assessment of Waterlogging and Salinization Hazards: a Review of Studies of the Irrigated Tracts in Desert Environments. Oikoassay 24. Available at http://www.jnu.ac.in/sss/cssp/Rajesh1.pdf. Accessed December 30, 2013.

[3] Bowonder B Ramana KV \& Rajagopal R (1986) Waterlogging in Irrigation Projects. Sadhana 9(3), 177-190.

[4] Chatterjee C, Kumar R, Chakravorthy B, Lohani AK \& Kumar S (2005) Integrating remote sensing and GIS techniques with groundwater flow modeling for assessment of waterlogged areas. Water Resource Management 19, 539-554. DOI: 10.1007/s11269-005-2071-4
[5] Choubey VK (1998) Assessment of Waterlogging in Sriram Sagar Command Area, India, by Remote Sensing. Water Resource Management 12(5), 343-357.

[6] Chowdary VM et al. (2008) Assessment of surface and sub-surface waterlogged areas in irrigation command areas of Bihar state using remote sensing and GIS. Agricultural Water Management 95, 754766. doi:10.1016/j.agwat.2008.02.009

[7] Crist EP \& Cicone RC (1984) A physically based transformation of Thematic Mapper data - the TM tasseled cap. IEEE Transactions on Geoscience and Remote Sensing 22, 256 - 263.

[8] DMP (2002, 2004, 2007 and 2011) Disaster Management Plan of East Medinipur. Office of the District Magistrate, East Medinipur, W.B

[9] Dwivedi RS (1994) Study of Salinity and Waterlogging in Uttar Pradesh (India) Using Remote Sensing Data. Land Degradation and Rehabilitation 5, 191-199.

[10]Dwivedi RS \& Sreeniwas K (2002) The Vegetation and Waterlogging Dynamics as Derived from Spaceborne Multispectral and Multitemporal Data. International Journal of Remote Sensing 21(3), 519-531.

[11]ERF (2011) Water Logging in Satkhira District: An Analysis of Gaps between Needs and Response. Early Recovery Facility, UNDP Bangladesh. Available at http://www.lcgbangladesh.org/DERweb/Needs\%20Assessment/Report s/waterlogging\%202011\%20Gap\%20analysis_final.pdf. Accessed January 01, 2014.

[12]ESRI (2014) Available at http://blogs.esri.com/esri/arcgis/2013/07/24/band-combinations-forlandsat-8\%. Accessed February 28, 2014.

[13]GAO BC (1996) NDWI - A normalized difference water index for remote sensing of vegetation liquid water from space. Remote Sensing of Environment 58, 257-266.

[14]Gupta SK (2002) A century of subsurface drainage research in India. Irrigation and Drainage Systems 16, 69-84.

[15] Goodwin NR, Coops NC, Wulder MA, Gillanders S, Schroeder TA \& Nelson T (2008) Estimation of insect dynamics using a temporal sequence of Landsat data. Remote Sensing of Environment 112, 36803689.

[16]Holden J, Howard AJ, West LJ, Maxfield E, Panter I \& Oxley J (2009) A Critical Review of Hydrological Data Collection for Assessing Preservation Risk for Urban Waterlogged Archaeology: A Case Study from the City of York, UK. Journal of Environmental Management 90, 3197-3204. DOI:10.1016/j.jenvman.2009.04.015.

[17]Huang J, Chen D \& Cosh MH (2009) Sub-pixel reflectance unmixing in estimating vegetation water content and dry biomass of corn and soybeans cropland using normalized difference water index (NDWI) from satellites. International Journal of Remote Sensing. 30(8), 20752104

[18]Jackson RD \& Huete AR (1991) Interpreting Vegetation Indices. Preventive Veterinary Medicine11, 185-200.

[19]Malik AI, Colmer TD, Lambers H, Setter TL \& Schortemeyer M (2002) Short-term Waterlogging has Long-term Effects on the Growth and Physiology of Wheat. New Phytologist 153, 225-236.

[20]Mcfeeters SK (1996) the Use of Normalized Difference Water Index (NDWI) in the Delineation of Open Water Features. International Journal of Remote Sensing 17, 1425-1432. 
[21]Merot Ph, Ezzahar B, Walter C \& Aurousseau P (1995) Mapping Waterlogging of Soils using Digital Terrain Models. Hydrological Processes 9, 27-34.

[22]Minar MH, Hossain B \& Shamsuddin MD (2013) Climate Change and Coastal Zone of Bangladesh: Vulnerability, Resilience and Adaptability. Middle-East Journal of Scientific Research 13(1), 114120. DOI: 10.5829/idosi.mejsr.2013.13.1.64121.

[23]Mukherjee S (1985) Floods in West Bengal: A Spatial and Temporal Analysis. In Geographical Mosaic - Professor K.G. Bagchi Felicitation Volume (Mukhopadhyay, S.C. ed.), Modern Book Agency Pvt. Ltd., Kolkata, 262-271.

[24]Nicholson SE \& Farrar TJ (1994) The Influence of Soil Type on the Relationships between NDVI, Rainfall, and Soil Moisture in Semiarid Botswana. I. NDVI Response to Rainfall. Remote Sens., Environ 50, 107-120.

[25]Quan RS, Liu M, Lu M, Zhang L, Wang J \& Xu S (2010) Waterlogging Risk Assessment Based on Land Use/Cover Change: a Case Study in Pudong New Area, Shanghai. Environ Earth Sci 61, 11131121. DOI 10.1007/s12665-009-0431-8.

[26]Qureshi AS, McCornick PG, Qadir M \& Aslam Z (2008) Managing Salinity and Waterlogging in the Indus Basin of Pakistan. Agricultural Water Management 96(1), 1-10.

[27]Sims DA \& Gamon JA (2003) Estimation of vegetation water content and photosynthetic tissue area from spectral reflectance: a comparison of indices based on liquid water and chlorophyll absorption features. Remote Sensing of Environment 84, 526-537.

[28]Tucker CJ (1979) Red and photographic infrared linear combinations for monitoring vegetation. Remote Sensing of Environment 8, 127150 .

[29]Tucker CJ \& Choudhury BJ (1987) Satellite remote sensing of drought conditions. Remote Sens. Environ 23, 243-251.

[30]Tucker CJ, Venerate CL, Sharman MJ \& Van Intercom G (1985) Satellite remote sensing of total herbaceous biomass production in the Senegalese Sahel: 1980- 1984. Remote Sens., Environ 17, 233-249.

[31]Tutu A (2005) River Management in Bangladesh: A People's Initiative to Solve Water-Logging. Available at http://pubs.iied.org/pdfs/G02131.pdf. Accessed January 01, 2014.

[32]Wilson EH \& Sader SA (2002) Detection of forest harvest type using multiple dates of Landsat TM imagery. Remote Sensing of Environment 80, 385-396.

[33]Xu H (2006) Modification of Normalised Difference Water Index (NDWI) to enhance open water features in remotely sensed imagery. International Journal of Remote Sensing 27(14), 3025-3033 